\title{
Feedback inhibition of apolipoprotein A-I synthesis by its propeptide in hepatocyte cell culture and in the cell-free system
}

\author{
Kurt Weigand ${ }^{1, *}$, Ute Tischler-David ${ }^{2}$, R Gebhardt $^{3,4}$, HW Steisslinger², Madlen Matz-Soja ${ }^{4}$ and Karl-Heinz Schmidt ${ }^{2}$ \\ ${ }^{1}$ Department of Medicine, Stauferklinik, Schwaebisch-Gmuend, Teaching Hospital of the University of Ulm, Germany \\ 2 Department of Surgery, University of Tuebingen, Germany \\ ${ }^{3}$ Department of Biochemisty, University of Tuebingen, Germany \\ ${ }^{4}$ Current address: Institute of Biochemisty, Faculty of Medicine, University of Leipzig, Germany
}

\begin{abstract}
Addition of chemically synthesized proapolipoprotein A-I hexapeptides in a concentration of $10^{-4} \mathrm{~mol} / \mathrm{l}$ in the medium of primary rat hepatocyte cell cultures decreased net apolipoprotein A-I synthesis by up to $13 \%$. The inhibition was dose dependent and slightly different for the three peptides with differing amino acid sequences. The synthesis of albumin remained unaltered. In a reticulocyte cell-free system the three propeptides, in a concentration of $10^{-4} \mathrm{~mol} / \mathrm{l}$, inhibited apolipoprotein synthesis by $42 \%, 43 \%$, and 48\%, respectively. Total protein synthesis was inhibited by $19 \%$, $22 \%$, and $24 \%$ only. All three propeptides in concentrations of $10^{-7}$ to $10^{-4} \mathrm{~mol} / \mathrm{l}$ inhibited apo A-I synthesis in a dose dependent manner, indicating that the identical C-terminal sequence (Phe-Trp-GIn-GIn) is responsible for the inhibitory effect. The synthesis of albumin was not inhibited. The proalbumin hexapeptide (Arg-Gly-Val-Phe-Arg-Arg) at a concentration of $10^{-3} \mathrm{~mol} / \mathrm{l}$ inhibited albumin synthesis by $63 \%$ whereas incorporation into apoA-I was inhibited by only $14 \%$. Amino acids in concentrations equimolar to the propeptides had no effect on the incorporation into total protein, apoA-I, and rat serum albumin. These results suggest that the synthesis of apolipoprotein A-I is regulated by a feedback mechanism with its propeptide as inhibitor.
\end{abstract}

Keywords: apolipoproteins; apo A-l; high density lipoproteins; chemical synthesis; lipoprotein metabolism; liver; propeptides; albumin

\section{Introduction}

A high serum level of HDL lowers the risk of myocardial infarction. The predominant protein associated with HDL is apoA-I which is synthesized in hepatocytes and enterocytes [1-3]. A high serum level of apoA-I lowers the risk of myocardial infarction [4, 5]. Although apoA-I plays a central role in the regulation of lipid metabolism and thus in prevention of myocardial infarction, little information is available on the regulation of its synthesis. ApoA-I is synthesized as a 267 amino acid precursor protein, preproapoA-I [6-13]. The presegment is 18 amino acids long and cotranslationally cleaved off, resulting in proapoA-I [11-16]. ProapoA-I is the precursor of the mature apoA-I, differing from apoA-I by a hexapeptide extension at the $\mathrm{N}$-terminal end [14]. For rat apoA-I three slightly different propeptides have been described: TrpGlu-Phe-Trp-GIn-GIn (WEFWQQ) [8], Ser-Glu-Phe-TrpGln-GIn (SEFWQQ) [15], and Trp-Asp-Phe-Trp-GIn-Gln (WDFWQQ) [16]. The amino acid sequence of the human propeptide has been shown to be Arg-His-Phe-Trp-GIn-GIn
(RHFWQQ) $[8,11,17]$. The apo A-I prosegment differs from propeptides of other serum proteins in two respects: it does not terminate with paired basic amino acids [6] and its processing is extracellular rather than intracellular [3, $8,14-20]$. The hexapeptide is slowly split off in plasma by *Corresponding author: Kurt Weigand, Staufer Hospital, Schwabisch
Gmund, Waldsiedlung 12, Germany. Tel.: 0049717163723; Fax:
00497171931482; E-Mail: k-weigand@t-online.de

Received 16 March 2017 Revised 10 May 2017 Accepted 28 May 2017 Published 28 May 2017

Citation: Weigand K, Tischler-David U, Gebhardt R, Steisslinger HW, MatzSoja M, Karl-Heinz S. Feedback inhibition of apolipoprotein A-I synthesis by its propeptide in hepatocyte cell culture and in the cell-free system. J Hepatol Gastroenterol. 2017; 2(3):12-17. DOI: 10.14312/2399-8199.2017-3

Copyright: ( 2017 Weigand K, et al. Published by NobleResearch Publishers. This is an open-access article distributed under the terms of the Creative Commons Attribution License, which permits unrestricted use, distribution and reproduction in any medium, provided the original author and source are credited. 
a $\mathrm{Ca}^{2+} / \mathrm{Mg}^{2+}$ dependent protease, located on the surface of plasma lipoprotein particles and endothelial cells [14]. The bone morphogenetic protein-1 has been identified as enzyme that cleaves human apolipoprotein A-I [21]. The procollagen C-proteinase enhancer is involved in the proteolytic processing of proapoA-I [22]. Several possible functions of the propeptide extension have been discussed. It may be involved in the formation of the tertiary structure of apoA-I or it may facilitate transport through or out of the cell $[23,24]$. In addition, the propeptide itself may have a biological function and be involved in the regulation of apoA-I synthesis, as has been described for other propeptides such as albumin [25] and procollagen [26-31]. All three rat propeptides were synthesized chemically. In order to test the hypothesis that the released propeptide is involved in the regulation of apoA-I synthesis, we studied the effect of the chemically produced hexapeptides on the synthesis of apoA-I in primary rat cell cultures and in a cellfree system. To evaluate the specificity of the inhibition we also studied the effect of the propeptide of albumin on albumin and on apoA-I synthesis.

\section{Materials and methods}

\section{Chemical synthesis of peptides}

The hexapeptides of proapoA-I and of proalbumin were synthesized conventionally, beginning from the C-terminal end by stepwise $\mathrm{N}$-terminal peptide chain elongation (Orpegen, Heidelberg, Germany). Details of the synthesis of the hexapeptides have been published previously [32]. Purity of the peptides was confirmed by thin-layer chromatography, HPLC, amino acid analysis and mass spectrometry [33]. Quality control of synthetic peptides was kindly performed by W.D. Lehmann, DKFZ Heidelberg, Germany.

\section{Purification of apolipoprotein A-I and antiserum preparation}

HDL was isolated from plasma of male Wistar rats by density gradient centrifugation according to [34] as described previously [35]. After centrifugation for 20 min at $1000 \mathrm{~g}$ at $4^{\circ} \mathrm{C}$, the supernatant was submitted to a density gradient of $\mathrm{KBr}$ and $\mathrm{NaCl}$ and centrifuged for $20 \mathrm{~min}$ at $3000 \mathrm{~g}$ at $4^{\circ} \mathrm{C}$. Aliquots of $4 \mathrm{ml}$ of the pooled HDL fractions were pipetted into polyallomer tubes. A discontinuous gradient was formed by carefully layering 3 $\mathrm{ml}$ of a $\mathrm{NaCl} / \mathrm{KBr}$ solution with a density of 1.063 above the serum, followed by $3 \mathrm{ml}$ of $\mathrm{NaCl} / \mathrm{KBr}$ solution with a density of $1.0191,23$ and centrifuged at $280.000 \mathrm{~g}$ at $20^{\circ} \mathrm{C}$ for $24 \mathrm{~h}$. Subsequently HDL was extensively dialysed against $\mathrm{PBS}+0.01 \%$ EDTA at $\mathrm{pH}$ 7.4. After extraction with ether/ethanol apoA-I was isolated by gel chromatography on a Sepharyl S-200 column and subsequently submitted to isoelectrofocusing at the $\mathrm{pH}$ range between 5.5 and 5.7. Peak 3 of the Sepharyl S-200 column showed one band at $\mathrm{pH}$ 5.6, indicating that apoA-I was pure (Figure 1). This band was eluted with $5 \mathrm{M}$ urea at $\mathrm{pH} 8.5$, extensively dialysed against $0.01 \mathrm{M} \mathrm{NH}_{4} \mathrm{HCO}_{3}+0.01$ EDTA at pH 7.4, and lyophilised [35, 36]. Purified apoA-I was used for production of specific antiserum by immunisation of rabbits. Purification of albumin and production of albumin antiserum was performed as described previously [37, 38].

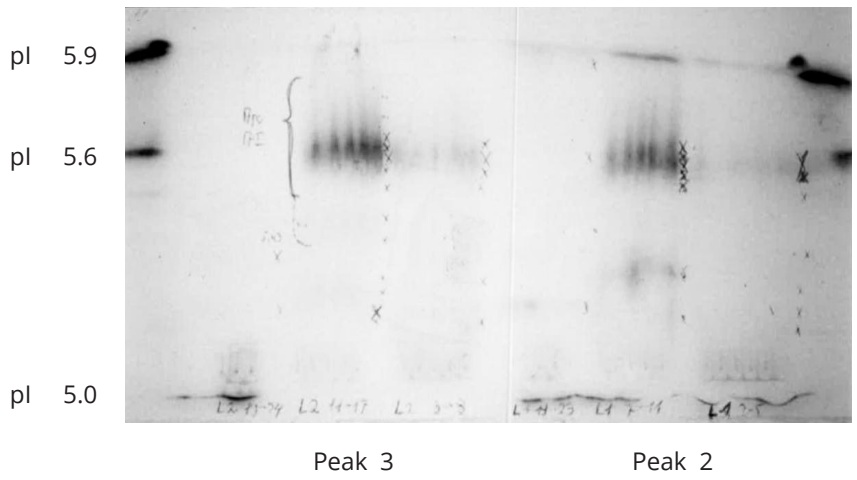

Figure 1 Peak 3 of the Sepharyl S-200 HR column showed one band at $\mathrm{pH}$ 5.6 by isoelectrofocusing, indicating that apoA-I was pure. This band was eluted with $5 \mathrm{M}$ urea, dialysed, and lyophilised and subsequently used for production of specific antiserum.

\section{Primary hepatocyte cell cultures}

Hepatocytes were isolated by perfusion of rat liver with collagenase [39]. Viability was estimated by Trypan blue staining. Hepatocytes were suspended to a concentration of about $10^{6}$ cells per $\mathrm{ml}$ in Williams medium containing $10 \%$ calf serum, $2 \mathrm{mM}$ glutamine, $50 \mathrm{U} / \mathrm{ml}$ penicillin, and $50 \mu \mathrm{m} / \mathrm{ml}$ streptomycin. Two hrs later medium was exchanged by serum free medium $[40,41]$. With the change of medium after $24 \mathrm{hrs}$ of incubation the peptides of apoAl were added in concentrations of $10^{-7}$ to $10^{-4} \mathrm{~mol} / \mathrm{l}$. Control cultures were incubated with peptide free medium or with the albumin hexapeptide in concentrations of $10^{-5}$ to $10^{-3} \mathrm{~mol} / \mathrm{l}$. Twenty four hrs later medium was withdrawn and centrifuged for $10 \mathrm{~min}$ at $3000 \mathrm{~g}$. Subsequently total protein, apoA-I and RSA concentrations were measured in the supernatant [42]. Each measurement of the proteins was done in duplicate. The mean value was calculated from six different cell cultures. The synthesis rate of apoA-I and albumin was related to total protein in the supernatant (ng/mg) and expressed in percent.

\section{Cell-free protein synthesis}

Total rat liver RNA was isolated by extraction with $7 \mathrm{M}$ guanidine- $\mathrm{HCL}$ and centrifugation on a $\mathrm{CsCl}$ gradient. Subsequently mRNA was isolated by chromatography on oligo (dT)-cellulose [42]. ${ }^{3} \mathrm{H}$ - leucine was incorporated into protein using a cell-free lysate from rabbit reticulocytes (NEN) with $1.5 \mu \mathrm{g}$ of the isolated m-RNA as described [25, 43]. The reaction mixture was incubated with hexapeptide concentrations from $10^{-8}$ to $10^{-4} \mathrm{~mol} / \mathrm{l}$ for $50 \mathrm{~min}$ at $37^{\circ} \mathrm{C}$.

Measurement of total protein, apolipoprotein A-I, and albumin

Total protein was measured in the supernatant of hepatocyte cell cultures and in the cell-free system by the Bio-rad assay with BSA as standard according to [44]. Total protein synthesis was measured as hot trichloroacetic acid insoluble radioactivity [45]. ApoA-I and albumin were measured in the supernatant by Elisa using a modified commercially available kit (Avidin alkaline phosphatase staining, Sigma) [46] by precipitation with specific antiserum.

\section{Statistical analysis}

Results are expressed as mean \pm SD of a number of 
determinations as indicated. The data were compared by Student's t test. Differences were considered to be statistically significant when $p<0.05$.

\section{Results}

Addition of WEFWQQ, WDFWQQ, and SEFWQQ to the cell culture, in concentrations of $10^{-7}$ to $10^{-4} \mathrm{~mol} / \mathrm{l}$, inhibited net increase of apoA-I dose dependent (Table 1). Compared to the control culture a peptide concentration of $10^{-4} \mathrm{~mol} / \mathrm{l}$ inhibited apoA-I synthesis to $87 \pm 4.9 \%, 90 \pm 1.9 \%$, and 94 $\pm 3.0 \%(n=6)$. WEFWQQ inhibited albumin synthesis only slightly, and not in dose dependent manner. The other two peptides did not affect albumin synthesis at all. For control of specificity the influence of the proalbumin hexapeptide Arg-Gly-Val-Phe-Arg-Arg (RGVFRR) was determined on the synthesis of apoA-I, rat serum albumin, and total protein in concentrations of the peptide from $10^{-5}$ to $10^{-3} \mathrm{~mol} / \mathrm{l}$ (n = 1). Proapo A-I synthesis was not influenced whereas rat serum albumin synthesis was inhibited in dose dependent manner. At a concentration of $10^{-3} \mathrm{~mol} / \mathrm{l}$ of RGVFRR albumin synthesis was inhibited to $77 \%$, confirming previous results in isolated hepatocytes [25].

Table 1 Influence of the pro-peptides on apolipoprotein A-I and albumin-synthesis in primary hepatocyte cell cultures.

\begin{tabular}{|c|c|c|c|c|}
\hline Peptide conc. in medium & $\begin{array}{l}n g \text { Apo A-I /mg } \\
\text { total protein } \pm S D\end{array}$ & $\%$ of control $\pm S D$ & $\begin{array}{l}\mu g \text { Albumin/mg } \\
\text { total protein } \pm S D\end{array}$ & $\%$ of control $\pm S D$ \\
\hline \multicolumn{5}{|l|}{ WEFWQQ $(n=6)$} \\
\hline Control & $118.0 \pm 13.1$ & 100.0 & $26.7 \pm 7.9$ & 100.0 \\
\hline $10^{-7} \mathrm{M}$ & $112.9 \pm 11.5$ & $95.7 \pm 4.3$ & $25.0 \pm 6.7$ & $93.6 \pm 2.4$ \\
\hline $10^{-6} \mathrm{M}$ & $109.0 \pm 15.4$ & $92.4 \pm 5.8$ & $24.3 \pm 4.5$ & $91.0 \pm 1.7$ \\
\hline $10^{-5} \mathrm{M}$ & $103.8 \pm 15.1$ & $88.0 \pm 6.1$ & $25.6 \pm 5.5$ & $95.9 \pm 2.1$ \\
\hline $10^{-4} \mathrm{M}$ & $102.4 \pm 13.8$ & $86.8 \pm 4.9$ & $25.2 \pm 5.6$ & $94.4 \pm 2.1$ \\
\hline \multicolumn{5}{|l|}{ WDFWQQ $(n=6)$} \\
\hline Control & $113.4 \pm 14.7$ & 100.0 & $24.7 \pm 2.9$ & 100.0 \\
\hline $10^{-7} \mathrm{M}$ & $111.2 \pm 15.5$ & $97.9 \pm 1.3$ & $26.6 \pm 3.1$ & $107.7 \pm 2.1$ \\
\hline $10^{-6} \mathrm{M}$ & $107.9 \pm 15.1$ & $95.0 \pm 2.4$ & $26.2 \pm 4.0$ & $106.1 \pm 1.8$ \\
\hline $10^{-5} \mathrm{M}$ & $108.2 \pm 12.6$ & $95.5 \pm 2.9$ & $26.2 \pm 3.8$ & $106.1 \pm 2.0$ \\
\hline $10^{-4} \mathrm{M}$ & $102.0 \pm 10.0$ & $90.4 \pm 1.9$ & $25.8 \pm 3.5$ & $104.7 \pm 1.4$ \\
\hline \multicolumn{5}{|l|}{$\operatorname{SEFWQQ}(n=4)$} \\
\hline Control & $117.8 \pm 5.2$ & 100.0 & $24.0 \pm 2.0$ & 100.0 \\
\hline $10^{-7} \mathrm{M}$ & $119.1 \pm 5.4$ & $100.9 \pm 1.5$ & $23.2 \pm 2.0$ & $97.1 \pm 6.6$ \\
\hline $10^{-6} \mathrm{M}$ & $114.6 \pm 6.1$ & $97.3 \pm 1.2$ & $23.9 \pm 2.0$ & $99.7 \pm 4.2$ \\
\hline $10^{-5} \mathrm{M}$ & $112.6 \pm 2.7$ & $95.7 \pm 2.7$ & $23.3 \pm 1.6$ & $97.4 \pm 5.8$ \\
\hline $10^{-4} \mathrm{M}$ & $110.7 \pm 1.9$ & $94.0 \pm 3.0$ & $23.6 \pm 2.1$ & $98.1 \pm 6.2$ \\
\hline \multicolumn{5}{|c|}{ RGVFRR albumin-hexapeptide $(n=1)$} \\
\hline Control & 125.3 & 100.0 & 31.0 & 100.0 \\
\hline $10^{-5} \mathrm{M}$ & 124.9 & 99.7 & 29.6 & 95.5 \\
\hline $10^{-4} \mathrm{M}$ & 124.1 & 99.0 & 27.2 & 87.7 \\
\hline $10^{-3} \mathrm{M}$ & 123.0 & 98.2 & 23.8 & 76.8 \\
\hline
\end{tabular}

Addition of WEFWQQ, WDFWQQ, and SEFWQQ to the cellfree system in concentrations of $10^{-8}$ to $10^{-4} \mathrm{~mol} / \mathrm{l}$ inhibited incorporation of ${ }^{3} \mathrm{H}$-leucine into apoA-I dose dependently (Figure 2). A peptide concentration of $10^{-4} \mathrm{~mol} / \mathrm{l}$ inhibited incorporation to $57 \pm 8 \%, 52 \pm 5 \%$, and $58 \pm 3 \%$ compared to the control $(n=7)$. Incorporation into total protein was less effected. A peptide concentration of $10^{-4} \mathrm{~mol} / \mathrm{l}$ inhibited incorporation to $76 \pm 5 \%, 78 \pm 2 \%$, and $81 \pm 3 \%$ only. Incorporation into albumin was not inhibited by the apoA-I propeptides. Amino acids in equimolar concentrations to the propeptides had no effect on the incorporation into total protein, apoA-I and rat serum albumin.

The proalbumin hexapeptide in concentrations from $10^{-6}$ to $10^{-3} \mathrm{~mol} / \mathrm{l}$ dose dependently inhibited albumin synthesis $(n=4)$. A concentration of $10^{-3} \mathrm{~mol} / /$ inhibited incorporation into albumin to $36 \pm 8 \%$ of pretreatment value, confirming previous results [25], whereas incorporation into apoA-I was inhibited to $86 \pm 3 \%$ only. The total protein synthesis was inhibited to $67 \pm 4 \%$. The inhibition of total proteinand albumin synthesis was also significantly different compared to the synthesis of apoA-I by addition of the albumin propeptide (RGVFRR). The inhibition of total protein- and apo Al synthesis was highly significantly different compared to albumin synthesis and the inhibition of apoAl synthesis was significantly stronger than the inhibition of total protein synthesis.

\section{Discussion}

A high level of HDL in serum reduces the risk of 


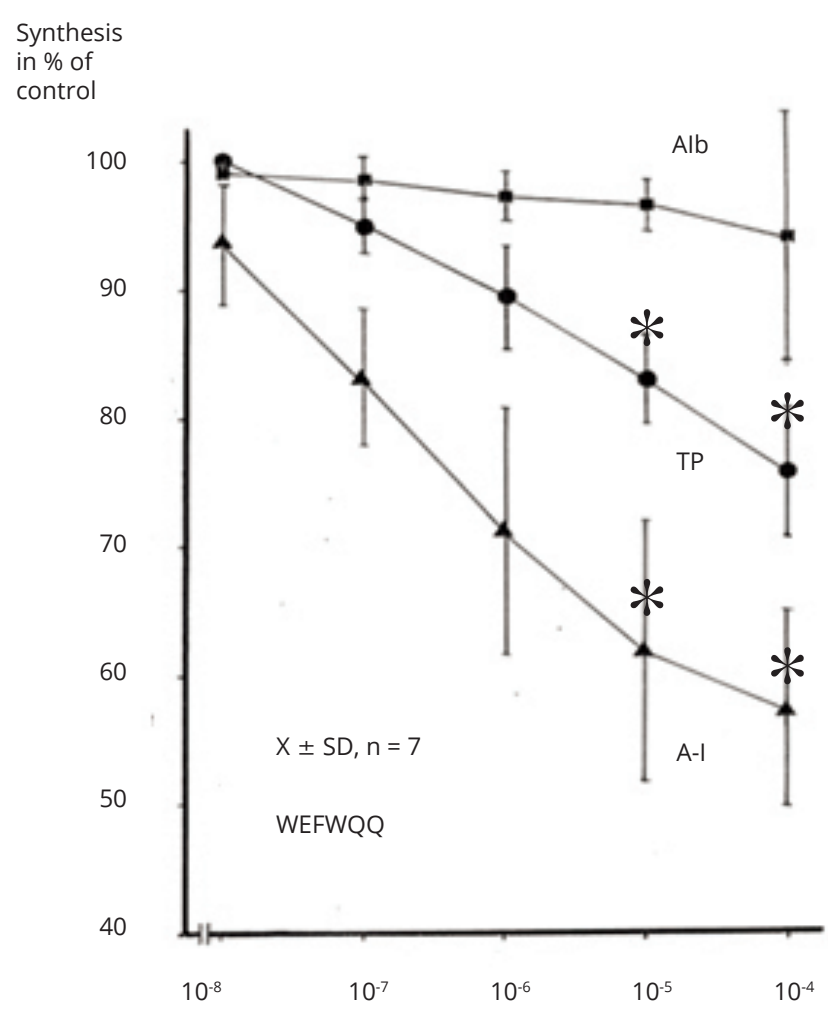

(a)

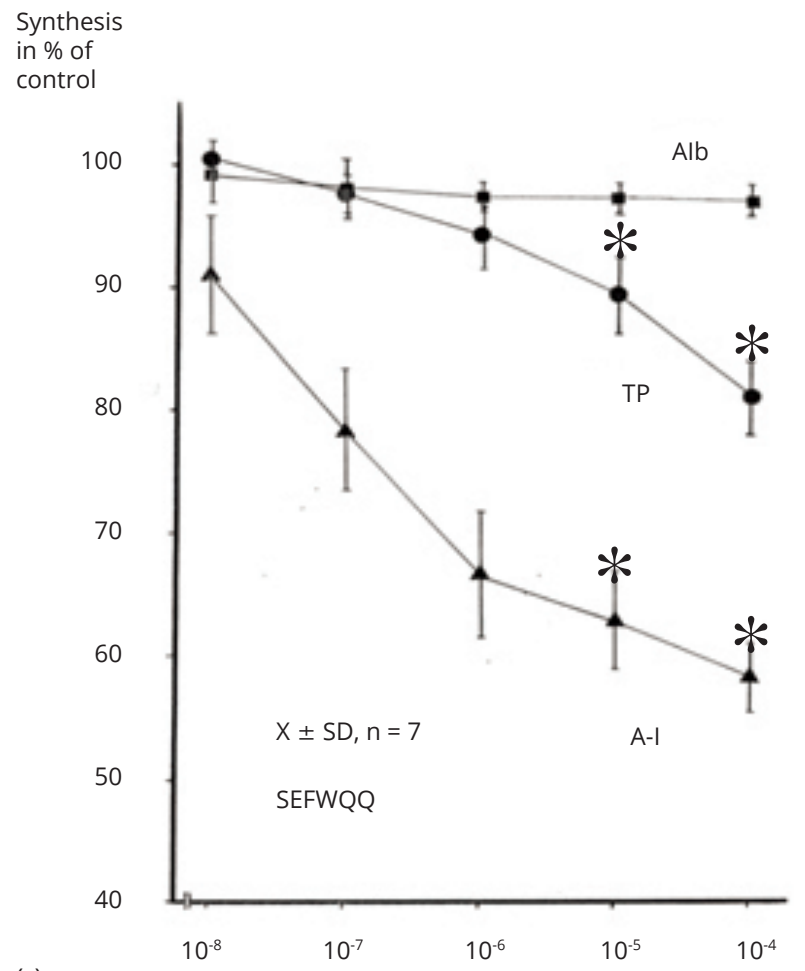

(c)

Hexapeptide mol/l

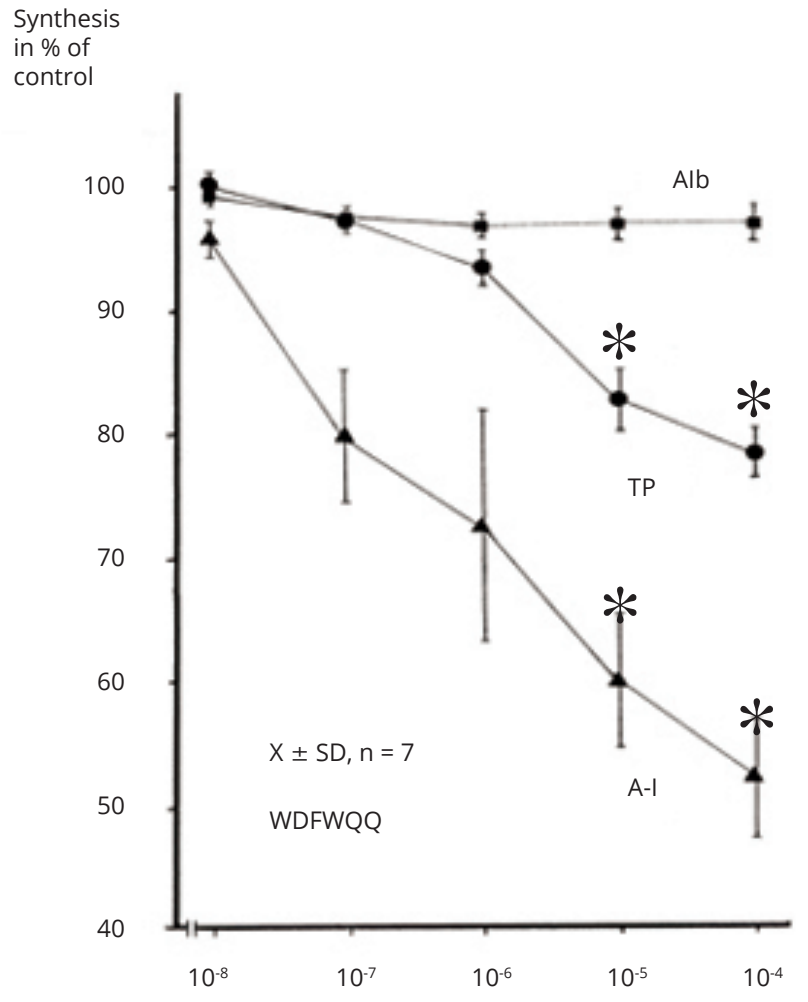

(b)
Synthesis

control

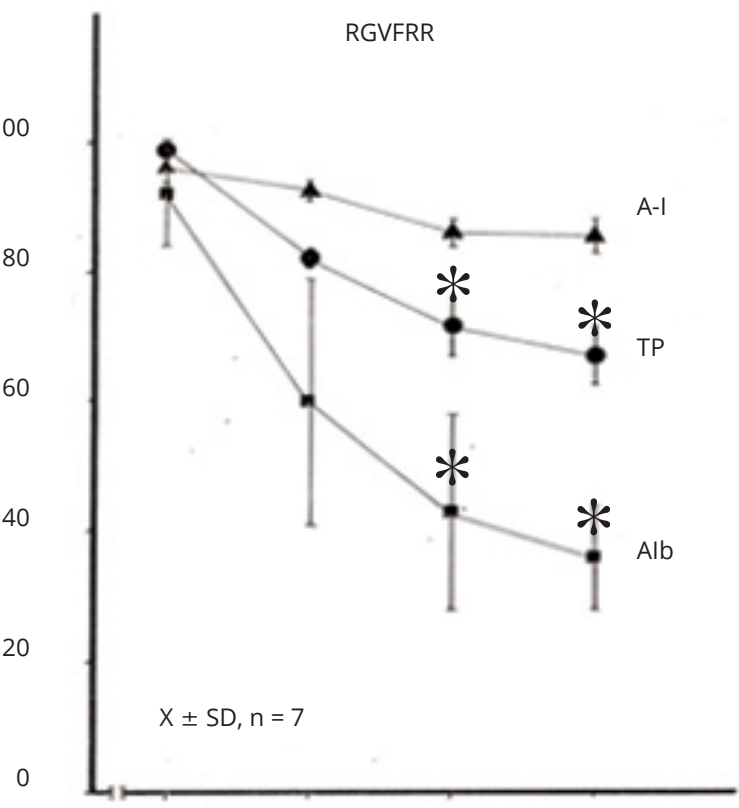

$10^{-6}$

$10^{-5}$

$10^{-4}$

$10^{-3}$

Hexapeptide mol/l

Figure 2abcd Influence the propeptides of apoA-I and albumin on the synthesis of apoA-I, total protein, and albumin in percent of the control (without peptides); ${ }^{*}(p<0.05)$.

atherosclerosis and myocardial infarction [4]. The major protein associated with high density lipoproteins is apoA-I and the apoB/apoA-I ratio is superior to any of the cholesterol ratios for estimation of the risk of acute myocardial infarction [47, 48]. ApoA-I is synthesized in the liver as preproprotein. It undergoes co-translational proteolytic processing to proapoAl which is secreted. Subsequently the propeptide is split off extracellularly 
[14]. Not all proapolipoprotein A-I molecules are converted to mature apolipoprotein [49]. In HDL, isolated from serum, 36\% of lipoprotein A-I was found in its pro form [50]. It has been shown that primary cell cultures of rat and human hepatocytes [51,52] and cell-free systems [9, 10,53] can synthesize apolipoprotein A-I. Therefore, these two systems allow the study of synthesis and regulation of apoA-I.

Three slightly different propeptides of apoA-I have been identified. However, the $\mathrm{COOH}$-terminal amino acids sequences of all three rat propeptides and also of the human propeptide are identical, indicating that these structures are essential for its function. Apo A-I synthesis is strongly inhibited by all three peptides in the cell fee system. In primary hepatocyte cell cultures apoA-I synthesis is although inhibited, but to a lesser degree. This may be due to a limited uptake or degradation of the peptides by the cells. The weaker inhibitory effect of SEFWQQ in the cell culture compared to the other two peptides may also be explained by a lower uptake rate of this peptide by the hepatocytes.

Albumin synthesis is not inhibited by the apoA-I propeptides, indicating a specific feedback inhibition of apoA-I synthesis by its propeptide. The specificity of this inhibition is further supported by the fact that the albumin propeptide inhibits the synthesis of albumin but not of apoA-I.

Proteolytic processing of proproteins can lead to biological active peptides, like insulin. For other peptides, released from proproteins, such as albumin and procollagen no definite biological functions have been demonstrated. An extensive review of structures, processing, and possible functions of propeptides are discussed by [54]. Interestingly, the synthesis of albumin and of procollagen type III are inhibited by their specific propeptides [25 -31]. Not only proteins which are synthesized via proproteins can be inhibited on the translational level. The key enzymes for the biosynthesis of polyamines, ornithine decarboxylase and S-adenosylmethionine decarboxylase are specifically inhibited by the polyamines spermine and spermidine [55]. We could demonstrate also that the synthesis of apolipoprotein A-I is specifically inhibited by its propeptide at the translational level. This is in agreement with the fact that the level of apolipoprotein A-I mRNA is primarily regulated post-transcriptionally through a higher stability or increased mRNA half-life, as has been reported [56]. Peptides with a low molecular weight can inhibit protein synthesis by binding to mRNA $[57,58]$. Whether the same mechanism is responsible for the inhibition of apoA-I synthesis by its propeptide remains to be investigated.

Many drugs have been developed to reduce the risk of atherosclerosis and myocardial infarction in patients with elevated cholesterol. The majority of these drugs reduce the LDL level. Only one drug on the market acts to increase the HDL level. Although this drug, torcetrapib, a cholesteryl ester transfer protein inhibitor, increases HDL cholesterol levels, it is not associated with a significant decrease in progression of coronary atherosclerosis [59]. However, this finding does not exclude a beneficial effect of increased HDL. The lack of efficacy may be related to the mechanism of action of torcetrapib or molecule specific effects [59]. Furthermore this drug was associated with an increase in systolic blood pressure [5961]. Therefore, it might well be that a drug stimulating apolipoprotein A-I synthesis and thus increasing HDL level by another mechanism, leads to a decrease in coronary events. Another approach to stimulating HDL may be with apolipoprotein A-I mimetic peptides which emulate many of the atheroprotective biological functions attributed to $\operatorname{HDL}[62,63]$. If the observed inhibition by its propeptide is of physiological relevance in the synthesis of apoA-I then a modified peptide, competing with the propeptide, may be able to increases the rate of synthesis of apoA-I. Such a drug would be easier to produce than a more complex apolipoprotein A-I mimetic peptide. In addition to its atheroprotective function a high level of apolipoprotein A-I may also be helpful in the prevention of Alzheimer's disease by modulation of Abeta aggregation [64].

\section{Conflicts of interest}

Authors declare no conflicts of interest.

\section{Acknowledgments}

This work was supported by the Deutsche Forschungsgemeinschaft (WE 461/6-2). We thankA. van Tol, Erasmus University, Rotterdam, Netherlands, for providing us with a sample of rat apoA-I antibody which enabled us to prove the purity of our antiserum. The critical review of the manuscript by Elizabeth Bird-Lieberman is gratefully acknowledged. Part of this work was presented at meetings of the AGA and AASLD and published in abstract form in Gastroenterology and Hepatology.

\section{Abbreviations}

ApoA-I: apolipoprotein A-I; HDL: high density lipoproteins; LDL: low density lipoproteins; RSA: rat serum albumin

\section{References}

[1] Glickman RM, Green PH. The intestine as a source of apolipoprotein Al. Proc Natl Acad Sci USA. 1977; 74(6):2569-2573.

[2] Wu AL, Windmueller HG. Relative contributions by liver and intestine to individual plasma apolipoproteins in the rat. J Biol Chem. 1979; 254(15):7316-7322.

[3] Sliwkowski MB, Windmueller HG. Rat liver and small intestine produce proapolipoprotein Al which is slowly processed to apolipoprotein $\mathrm{Al}$ in the circulation. J Biol Chem.1984; 259(10):6459-6465.

[4] Stampfer MJ, Sachs FM, Salvini S, Willet WC, Hennekens CH. A prospective study of cholesterol, apolipoproteins, and the risk of myocardial infarction. N Engl J Med. 1991; 325(6):373-381.

[5] Freedman DS, Srinivasan SR, Shear CL, Franklin FA, Webber LS, et al. The relation of apolipoprotein A-I and $B$ in children to parental myocardial infarction. N Engl J Med. 1986; 315(12):721-726.

[6] Gordon JI, Smith DP, Andy R, Alpers DH, Schonfeld G, et al. The primary translation product of rat intestinal apolipoprotein A-I mRNA is an unusual preprotein. J Biol Chem. 1982; 257(14):971-978.

[7] Gordon Jl, Sims HF, Lentz SR, Edelstein C, Scanu AM, et al. Proteolytic processing of human preproapolipoprotein A-I. A proposed defect in the conversion of pro A-I to A-I in Tangier's disease. J Biol Chem. 1983; 258(6):4037-4044.

[8] Gordon JI, Sims HF, Strauss AW, Scanu AM, Edelstein C, et al. Proteolytic processing and compartmentalization of the primary translation products of mammalian apolipoprotein mRNAs. CRC Crit Rev Biochem. 1986; 20(1):37-71.

[9] Stoffel W, Krüger E, Deutzmann R. Cell-free translation of human liver apolipoprotein A-I and A-II mRNA processing of primary translation products. Hoppe Seylers Z Physiol Chem. 1983; 364(3):227-237.

[10] Stoffel W, Blobel G, Walter P. Synthesis in vitro and translocation of apolipoprotein Al across microsomal vesicles. Eur J Biochem. 1981; 120(3):519-522 
[11] Ghiselli G, Sherrill BC. Proapolipoprotein A-I metabolism in the human and the rat. Adv Exp Med Biol. 1985; 183:113-120.

[12] Brewer HB, Ronan R, Meng M, Bishop C. Isolation and characterization of apolipoproteins A-I, A-II, and A-IV. Methods Enzymol. 1986; 128:223246.

[13] Bojanovski D, Gregg RE, Ghiselli G, Schaefer EJ, Light JA, et al. Human apolipoprotein A-I isoprotein metabolism: ProapoA-I conversion to mature apo-A-I. J Lipid Res. 1985; 26(2):185-193.

[14] Kooistra T, van Hinsbergh V, Havekes L, Kempen HJ. In vitro studies on origin and site responsible for conversion of human proapoprotein A-I into apoprotein A-I. FEBS Lett. 1984; 170(1):109-113.

[15] Ghiselli G, Bradley WA, Gott AM, Sherill BC. Identification of proapo A-I in rat lymph and plasma: Metabolic conversion of mature apo A-I in the circulation. Biochem Biophys Res Commun. 1983; 116(2):704-711.

[16] Stoffel W, Niedel B. Processing of proapolipoprotein A-I requires specific conformation. Biol Chem Hoppe-Seyler. 1985; 366(2):181187.

[17] Zannis VI, Karathanasis SK, Keutmann, HT, Goldberger G, Breslow JL. Intracellular and extracellular processing of Human apolipoprotein A-l: Secreted apolipoprotein A-I- isoprotein is a propeptide. Proc Natl Acad Sci USA. 1983; 80(9):2574-2578.

[18] Edelstein C, Gordon Jl, Toscas K, Sims HF, Straus AW, et al. In vitro conversion of proapoprotein A-I to apoprotein A-I. Partial characterization of an extracellular enzyme activity. J Biol Chem. 1983; 258(19):11430-11433.

[19] Ghiselli G, Gotto AM Jr, Tannenbaum S, Sherrill BC. Proapolipoprotein A-I conversion kinetics in vivo in human and in rat. Proc Natl Acad Sci USA. 1985; 82(3):874-878.

[20] Stoffel W, Knyri K, Bode C. A Serum proteinase converts proapolipoprotein Al secreted by rat hepatocytes to a mature apolipoprotein. Hoppe-Seylers Z Physiol Chem. 1983; 364(11):16311640.

[21] Chau P, Fielding PE, Fielding CJ. Bone morphogenetic protein-1 (BMP-1) cleaves human proapolipoprotein $\mathrm{A} 1$ and regulates its activation for lipid binding. Biochemistry. 2007; 46(28):8445-8450.

[22] Francone OL, Ishida BY, de la Llera-Moya M, Royer L, Happe C, et al. Disruption of the murine procollagen $\mathrm{C}$-proteinase enhancer 2 genes causes accumulation of pro-apoA-I and increased HDL levels. J Lipid Res. 2011; 52(11):1974-1983.

[23] McLeod RS, Robbins C, Burns A, Yao Z, Pritchard PH. Deletion of the propeptide of apolipoprotein A-I impairs exit of nascent apolipoprotein A-I from the endoplasmic reticulum. Biochem J. 1994; 302(Pt 3):641648.

[24] Pyle LE, Fidge NH, Barton PA, Luong A, Sviridov D. Production of mature human apolipoprotein A-I in a baculovirus-insect cell system: Propeptide is not essential for intracellular processing but may assist rapid secretion. Anal. Biochem. 1997; 253(2):253-258.

[25] Weigand K, Schmid M, Villringer A, Birr CH, Heinrich PC. Hexa-and Pentapeptide extension of proalbumin: Feedback inhibition of albumin synthesis by its propeptide in isolated hepatocytes and in the cell-free system. Biochemistry. 1982; 21(24):6053-6059.

[26] Wiestner M, Krieg T, Hörlein D, Glanville RW, Fietzek P, et al. Inhibiting effect of procollagen peptides on collagen biosynthesis in fibroblast cultures. J Biol Chem. 1979; 254(15):7016-7023.

[27] Hörlein D, McPherson J, Goh SH, Bornstein P. Regulation of protein synthesis: Translational control by procollagen- derived fragments. Proc Natl Acad Sci USA. 1981; 78(10):6163-6167.

[28] McPherson JM, Hörlein D, Abbott-Brown D, Bornstein P. Inhibition of protein synthesis in vitro by procollagen - derived fragments is associated with changes in protein phosphorylation. J Biol Chem. 1982; 257(15):8557-8560.

[29] Perlish JS, Timpl R, Fleischhauer R. Collagen synthesis regulation by the aminopropeptide of procollagen I in normal and scleroderma fibroblasts. Arthritis and Rheumatism 1985; 28(6):647-651.

[30] Paglia LM, Wilczek J, De Leon LD, Martin GR, Hörlein D, et al. Inhibition of procollagen cell-free synthesis by amino-terminal extension peptides. Biochemistry. 1979; 18(22):5030-5034.

[31] Paglia LM, Wiestner M, Duchene M, Oulette LA, Hörlein D, et al. Effects of procollagen peptides on the translation of type ll collagen messenger ribonucleic acid and on collagen biosynthesis in chondrocytes. Biochemistry. 1981; 20(12):3523-3527.

[32] Birr C, Weigand K, Turan A. The hexa-and pentapeptide extension of proalbumin: I. Chemical synthesis of serum albumin propetides. Biochim Biophys Acta. 1981; 670(3):421-423.

[33] Lehmann WD, Kessler M, König WA. Investigation on basic aspects of fast atom bombardment mass spectrometry: Matrix effects, sample effects, sensitivity and quantification. Biomedical Mass Spectrometry. 1984; 11(5):217-222.

[34] Redgrave TG, Roberts, DCK, West CE. Separation of plasma lipoproteins by density-gradient ultracentrifugation. Analyt Biochem. 1975; 65(12):42-49.

[35] Tischler U, Rückert D, Schubert R, Jaronie HW, Schmidt KH. Non-leaky vesiculation of large unilamellar vesicles (LUV) Induced by plasma high density lipoproteins (HDL): Detection by HPLC. Biochem Biophys Res Commun. 1989; 160(3):1219-1226.
[36] Mills GL, Lane PA, Weech PK. Laboratory techniques in biochemistry and Molecular biology: A Guidebook to lipoprotein techniques, Vol 14, $1^{\text {st }}$ edition. Elsevier. 1984

[37] Schreiber G, Roterrmund HM, Maeno H, Weigand K, Lesch R. The proportion of the incorporation of leucine into albumin to that into total protein in rat liver and hepatoma Morris 5123 TC $\neq$. European J Biochem. 1969; 10(2):355-361.

[38] Weigand K, Alpert E, Keutmann H, Isselbacher KJ. Purification and characterization of monkey albumin and proalbumin. Comp Biochem Physiol. 1980; 67(1):115-119.

[39] Weigand K, Müller M, Urban J, Schreiber G. Intact endoplasmic reticulum and albumin synthesis in rat liver cell suspensions. Exp Cell Res. 1971; 67(1):27-32.

[40] Gebhardt R, Fitzke H, Fausel M, Eisenmann-Tappe I, Mecke D. Influence of hormones and drugs on glutathione-S-transferase levels in primary culture of adult rat hepatocytes. Cell Biol Toxicol. 1990; 6(4):365-378.

[41] Gebhardt R, Fischer S. Enhanced sensitivity of perifused primary rat hepatocytes to mitogens and growth modulation by carcinogens. Toxicol In Vitro. 1995; 9(4):445-451.

[42] Aviv $H$, Leder P. Purification of biologically active globin messenger RNA by chromatography on oligothymidylic acid-cellulose. Proc Natl Acad Sci USA. 1972; 69(6):1408-1412.

[43] Kühn B, Alonso A, Heinrich PC. The effect of D-galactosamine and actinomycin $D$ on polysomes and messenger RNA levels in rat liver. Mol Pharmacol. 1981; 19(1):103-108.

[44] Bradford MM. A rapid and sensitive method for the quantitation of microgram quantities of protein utilizing the prinziple of protein-dye binding. Anal Biochem. 1976; 72(1-2):248-254.

[45] Mans RJ, Novelli GD. Measurement of the incorporation of radioactive amino acids into protein by a filter-paper disk method. Arch Biochem Biophys. 1961; 94:48-53.

[46] Lin RC. Quantification of apolipoproteins in rat serum and in cultured rat hepatocytes by enzyme-linked immunosorbent assay. Anal Biochem. 1986; 154(1):316-326.

[47] McQueen MJ, Hawkwn S, Wang X, Ounpuu S, Sniderman A, et al. Lipids, lipoproteins, and apolipoproteins as risk markers of myocardial infarction in 52 countries (the INTERHEART study): A case-control study. Lancet. 2008; 372(9634):224-233.

[48] Parish S, Peto R, Palmer A, Clarke R, Lewington S, et al. International Studies of Infarct Survival Collaborators. The joint effects of apolipoprotein A1, LDL cholesterol, and HDL cholesterol on risk: 3510 cases of acute myocardial infarction and 9805 controls. Eur Heart J. 2009; 30(17):2137-2146.

[49] Getz GS, Reardon.CA. Cubbing in proapolipoprotein maturation. J Lipid Res. 2011; 52(11):1861-1864.

[50] Dallinga-Thie GM, van't Hooft FM, van Tol A. Comparison of the metabolic behavior of rat apolipoproteins A-I and A-IV, isolated from both lymph chylomicrons and serum high density lipoproteins. Int J Biochem. 1986; 18(4):383-388.

[51] Krul ES, Dolphin PJ, Rubinstein D. Secretion of nascent lipoproteins by isolated rat hepatocytes. Can J Biochem. 1981; 59(8):676-686.

[52] Bouma ME, Pessah M, Renaud G, Amit D, Catala D, et al. Synthesis and secretion of lipoproteins by human hepatocytes in culture. In Vitro Cell Dev Biol. 1988; 24(2):85-90.

[53] Lin-Su MH, Lin-Lee YC, Bradley WA, Chan L. Characterization, cell-free synthesis, and processing of apolipoprotein A-I of rat high-density lipoproteins. Biochemistry. 1981; 20(9):2470-2475.

[54] Dean RT, Judah JD. Posttranslational proteolytic processing of polypeptides. In Florkin M, Stotz EH. Comprehensive Biochemistry 1980; 19 B Protein Metabolism, Part I, Elsevier, Amsterdam.

[55] Kameji T, Pegg AE. Inhibition of translation of mRNAs for ornithine decarboxylase and S-adenosylmethionine decarboxylase by polyamines. J Biol Chem. 1987; 262(6):2427-2430.

[56] Panduro A, Lee YCL, Chan L, Shafritz DA. Transcriptional and posttranscriptional regulation of apolipoprotein $\mathrm{E}, \mathrm{A}-\mathrm{I}$, and A-II gene expression in normal rat liver and during several pathophysiologic states. Biochemistry. 1990; 29(36):8430-8435.

[57] Hillar M, Pryzyjemski J. Control of transcription and translation by low molecular weight peptides (deprimerones) from chromatin and poly (A)-messenger RNA. Biochim Biophys Acta. 1979; 564(2):246-263.

[58] Wickens MP, Dahlberg JE. RNA-protein interactions: An overview. Cell. 1987: 51(3):339-342

[59] Nissen SE, Tardif JC, Nicolls SHJ, Revkin JH, Shear CL, et al. Effect of torcetrapib on the progression of coronary atherosclerosis. N Engl J Med. 2007; 356(13):1304-1315.

[60] Tall AR. CETP inhibitors to increase HDL cholesterol levels. N Engl J Med. 2007; 356(13):1364-1366.

[61] Rader DJ. Illuminating HDL-is it still a viable therapeutic target? N Engl Med. 2007; 357(21):2180-2183.

[62] Mendez Al. The promise of apolipoprotein A-I mimetics. Curr Opin Endocrinol Diabetes Obes. 2010; 17(2):171-176.

[63] Song X, Fischer P, Chen X, Burton C, Wang J. An apoA-I mimetic peptide facilitates off-loading cholesterol from HDL to liver cells through scavenger receptor BI. Int J Biol Sci. 2009; 5(7):637-646.

[64] Paula-Lima AC, Tricerri MA, Brito-Moreira J, Bomfirm TR, Oliveira FF, et al. Human apolipoprotein binds amyloid-beta and prevents Abetainduced neurotoxicity. Int J Biochem Cell Biol. 2009; 41(6):1361-1370. 